\title{
Conceptual Model of User Satisfaction as Mediator of E-Learning Services and System Quality on Students' Individual Performance
}

\author{
Muhammad Hafiz Riandi ${ }^{1 *}$, Harianto Respati ${ }^{2}$, Syarif Hidayatullah ${ }^{3}$ \\ ${ }^{I}$ Graduate School, University of Merdeka Malang, Malang, Indonesia \\ ${ }^{2,3}$ Department of Economics and Business, University of Merdeka Malang, Malang, Indonesia
}

\begin{abstract}
This study aims to collect the required information to construct a conceptual model to measure e-learning information system success in higher education setting. The methodology used in this study is literature study which was done by comparing six articles from international journals across the globe. Other articles as well as books were also used to support the findings in this study. Further in-depth study and comparisons was made to find suitable variables to evaluate e-learning system success. The conclusion of this study is a conceptual model which implements user satisfaction as mediating variable of the relationship of elearning service quality and system quality on students' individual performance as a measure of e-learning system success. Furthermore, this conceptual model can be an essential reference to be implemented in further related research.
\end{abstract}

Keywords: e-learning, individual performance, higher education, information system, service quality, students, system quality, user satisfaction.

\section{Introduction}

The use of information technology and communication (ICT) for educational purposes has been widely developed and researched [1]. Many terms represent this approach, such as distance learning, e-learning, and blended learning. Since the late 90's the use of ICT has been implemented for education, and its development is rapid until now [2]. Nowadays, this approach has already used to assist an educational process using laptops, PC, smartphone, and tablets through the internet [3].

Before COVID-19 pandemic, Indonesia has a high technology adoption level, although the development and access quality is relatively low [4]. However, during this pandemic situation from the beginning of March 2020, all the educational activities must be done online to prevent virus spread [5]. This opened up the possibility that Indonesian educators should utilize to familiarize themselves with elearning tools to substitute their face-to-face classroom learning sessions. In essence, technology has become a fundamental need for educational purposes from elementary school to higher education level in Indonesia during Covid-19 pandemic [6]-[8].

In Indonesia, many educational institutions, especially higher education institutions, have started using Zoom and Google
Meet to conduct their learning sessions [9]. Of course those two applications are sufficient to substitute for classroom sessions, however some other higher education institutions also started to optimize their previously-developed learning management systems. Examples of these systems are e-learning system in State University of Malang [10], Virtual Learning Management system in Brawijaya University [11], as well as eBelajar in STIKI [12]. These systems have been developed and updated for years, however their workload increases during this pandemic time as more educators started using them only after the pandemy started and thus their performance must be evaluated to examine their shortcomings and to better improve them in the future. Furthermore, as students are the most important stakeholders in e-learning system and their satisfaction is the benchmark for e-learning information system success, this study will mainly focus on students' usage and performance in utilizing e-learning system [13], [14].

From an Information System (IS) point of view, many proposed and recommended models estimate and explain technology usage such as DeLone and McLean Information Systems Success Model (DMISSM) [15], [16], Diffusion of Innovation (DOI) Theory [17], The Model of PC Utilization [18], Unified Theory of Acceptance and Use of Technology [19], and so on. In a sense, these theories only examine the use of technology empirically without evaluating the technology's application [20]. However, in line with the development of technology, research related to the system evaluation has changed. In the last five years, the research trends emphasize system usability associated with individual performance to measure the system effectiveness [9], [21]-[27]. In its application, many aspects influence individual performance. In this case, to measure the individual performance, those affecting aspects are system and service quality of the system, as well as user satisfaction. Based on the description, this study aims to propose a conceptual model for evaluating individual performance.

\section{Methodology}

This study used literature study. For literature study,

*Corresponding author: muhammad.hafiz.riandi@gmail.com 
researcher study researches done in the past related to Information System Success and variables used in measuring them. Literatures being compared for variables are studies done by Delone and McLean (1992 and 2003) [15], [16], Althonayan and Althonayan (2017) [28], Wahyudi et.al (2017) [27], Aldholay et al. (2019) [29], and Chopra et al. (2019) [30]. Other references from other journals and books are used as well to support this study. This study was done in a month to examine articles mentioned as well as finding other supporting materials. Comparative analysis method was used to compare between the articles to find suitable variables for the conceptual model.

\section{Literature Study}

Delone and McLean proposed in 1992 that information system success be measured by evaluating system quality and information quality which then linked to actual usage and user satisfaction which will further affect individual impact and collectively these individual impacts will also affect organizational impact [15]. In 2003, Delone and McLean then updated their previous model and proposed Information Quality, System Quality, and Service Quality would affect intention to use (which is closely related to actual usage) and user satisfaction which will further impact net benefits [16].

Jump forward into 2017, Althonayan and Althonayan derive their model from DeLone and McLean Information System Success Model (DMISSM), Task-Technology Fit (TTF) model by Goodhue (1995) and End User Computing Satisfaction (EUCS) Model by Doll and Torkzadeh. Their model showed how management quality, service quality, and system quality affect stakeholders' performance in King Saud University (KSU) MADAR ERP system [28]. In the same year, Wahyudi et al. also used DMISSM to evaluate the success of DAPODIK Information System for Public Senior High Schools in Indonesia using user satisfaction as mediator variable to examine the relationship between System Quality and Information Quality towards Net Benefit of the system [27].

Finally, in 2019, Aldholay et al. conducted research on online learning in Yemen based on DMISSM by using three variables - overall quality (consisting of system quality, information quality, and service quality), transformational leadership, and compatibility - which affect user satisfaction and actual usage that in turn affect performance impact [29]. On the other hand, Chopra et al. also conducted study in the same year to examine the success of Coursera as e-learning platform used by students in universities of north India. The study used a derivation of DMISSM to examine the effect of e-learning system (consisting of system quality, information quality, and service quality) towards e-learning effectiveness (consisting of net benefits and user satisfactions) [30].

Table 1 below shows variables used in previous studies done in measuring system information success.

\section{Discussions}

The Information Systems Success Model proposed by Delone and McLean has been widely used, modified and even updated after 10 years by its own creator [15], [16]. The updated version of DMISSM included Service Quality which was not included in the initial model as well as condensing individual impact and organizational impact into a variable called net benefit [16]. This model (either the first one or the updated one) is then used as a base model in many studies done by other researchers to measure the success of Information System and oftentimes this model was modified further to better reflect the system being evaluated by said researchers. The variables used in measuring systems are mostly the overall quality of the system itself (usually consist of System Quality, Information Quality and Service Quality), as well as user satisfaction and stakeholder or user performance which at times translated into a more holistic net benefit variable [27]-[30].

Althonayan and Althonayan (2017), Aldholay et al. (2019) and Chopra (2019) are all measuring Information Systems used in higher education institutions [28]-[30] which are suitable to be used as better references in this study which will also observe Information System in e-learning of a higher education institution. User Satisfaction is being measured in all studies compared except in the study done by Althonayan and Althonayan (2017) as it directly links system quality and service quality as well as management quality to stakeholders' performance [31]. Out of all six studies Chopra et al. (2019) measure the success of e-learning system by evaluating the responses and results of students in educational setting, although the study itself did not use examine the link between user satisfaction and net benefit, instead combining them into a variable called e-learning effectiveness [30].

Based on the study done on literatures above, the conceptual model that will be proposed in this study would include four variables which are System Quality, Service Quality, User Satisfaction, and Individual Performance.

\section{A. System Quality}

The system quality becomes the primary aspect that can be used as a measurement for the success of an information system

Table 1

Variables used in Measuring Information System Success

\begin{tabular}{|c|c|c|c|c|c|}
\hline $\begin{array}{c}\text { DeLone and McLean } \\
(1992)\end{array}$ & $\begin{array}{c}\text { DeLone and McLean } \\
(2003)\end{array}$ & $\begin{array}{c}\text { Althonayan and } \\
\text { Althonayan (2017) }\end{array}$ & $\begin{array}{c}\text { Wahyudi et al. } \\
\text { (2017) }\end{array}$ & $\begin{array}{c}\text { Aldholay et al. } \\
(2019)\end{array}$ & $\begin{array}{c}\text { Chopra et al. } \\
\text { (2019) }\end{array}$ \\
\hline Information Quality & Information Quality & System Quality & Information Quality & Information Quality & Information Quality \\
\hline Use & Service Quality & Service Quality & User Satisfaction & Service Quality & Service Quality \\
\hline Individual Impact & Use & & & Compatibility & Net benefit \\
\hline Organizational Impact & User Satisfaction & & & User Satisfaction & \\
\hline
\end{tabular}


(IS) [32], [33]. A high quality IS is a system that reaches the needs and expectations of users. To qualify as a good IS, it needs a well-designed system, providing and developing various assistance and information. A provider that delivers and maintains the IS is a crucial role to success in satisfying users. In this case, a university should take an evaluation of its elearning. The assessment based on the user feedback will improve the quality of e-learning. This action will give benefits to the institutions for the long term.

In this study, system quality is related to the students' experiences while using an e-learning, such as ease of use, ease of understanding, ease of learning, also interesting. Moreover, the system quality will affect a user satisfaction and system usability [34]. In this case, the quality of e-learning can be measured from several aspects, which are ease of use, flexibility, and timeliness. Ease of use is referred to as the performance characteristics of the system [35]. It is also related to the system that ease to use, ease to understand, and ease to learn. The next aspect is flexibility, which is the ability to respond effectively to a changed situation [36]. An essential thing in system usage is time-saving, reducing redundancy, and increasing productivity. Therefore, timeliness becomes an aspect that affects the system quality.

\section{B. Service Quality}

Service quality is defined as the difference between student expectations and experiences [37]. It plays a key role in strengthening competitive advantage by providing something unique or adding something extra, increasing user's satisfaction [38]. For educational purposes, a service quality such as elearning can improve a learning service through online media [39]. The system administrator also can improve its service through periodic interaction and from user feedback. The service quality can be measured by interactivity, functionality, and responsiveness to fulfill user expectations and satisfaction [40].

In the e-learning system, five main factors represent service quality: administrative and support, instructor quality, accuracy, course materials, and security [38]. Good service quality certainly will bring a positive impact on user satisfaction and performance. Therefore, service quality becomes one of the main aspects to be considered as a success of IS. To reach a good service of IS in education, universities have to improve elearning quality. The improvement can be performed through evaluation based on students' experiences and perceptions.

\section{User Satisfaction}

In IS, user satisfaction is considered the main indicator in all information systems success fields, especially in the education field [14], [29]. It can be measured in terms of user experience, function, and usability [41]. In other words, user satisfaction is related to the e-learning system effectiveness in fulfilling student needs [30], [42]. As an assistance tool, an e-learning system is expected can improve and fulfilled a student's objective [43], [44]. The IS must provide all the required content, function, and facilities that can support the students.

All those requirements will represent user satisfaction in content quality, system usability, and technical aspect. User satisfaction is defined in the e-learning system by increasing students' skills and knowledge [45]. With a high level of user satisfaction, it represents that the system can be useful for students as end-users and institutions as providers. Moreover, satisfaction constructs such as system and service quality are used in previous related research to evaluate e-learning effectiveness [46]-[48].

\section{Individual Performance}

Individual performance is related to the improved quality of work while using a system [49]. Those improvements include helping to complete tasks quickly, enabling command over work, improving job performance, minimizing errors, and optimizing workplace efficiency [50], [51]. A good humancomputer interaction is considered to increase individual performance. Therefore, this thing is related to the system and service quality of the system that affects user satisfaction.

As an end-user of the e-learning system, students' performance becomes the main consideration to measure the system's success. Thus, in this study, individual performance is related to the students' performance improvement while using an e-learning. The improvements are resource savings, efficiency, student's ability and knowledge achievement [22].

\section{Conceptual Model}

This preliminary study will produce a conceptual model to examine e-learning system success model through students' satisfaction and performance. A literature study has been done by collecting data and information in scientific journals and books related to the study. Therefore, this section will provide information and propose a conceptual model to measure a students' individual performance through e-learning.

Based on the previous section, four aspects were used in this study. These aspects include two independent variables, which are system quality and service quality, one mediating variable, which is user satisfaction, and one dependent variable, which is students' individual performance. Figure 1 represents the conceptual model of this study.

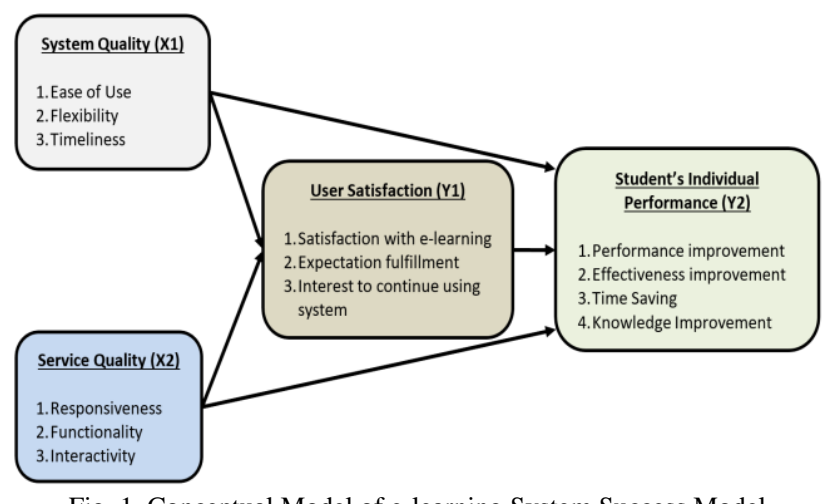

Fig. 1. Conceptual Model of e-learning System Success Model

The base of the proposed conceptual model is DMISSM. This model was selected because it is ideal and useful for evaluating an IS through user satisfaction and has been widely used in previous related research to measure the success of IS 
[22]. One of DMISSM characteristics is the use of user satisfaction as a mediating variable. This variable is used to bridge and further explain the relationship between the independent and dependent variables. This will then help examine how e-learning system and service quality will affect students' individual performance through user satisfaction. The model was adopted and adjusted with several related studies, such as students' perspectives on e-learning effectiveness [29], [30], and user performance using ERP in higher education [28].

From Figure 1, it can be seen that each variable has several indicators to measure it. In a system quality (X1) variable, three indicators can represent it. The first indicator is the ease of use, which explains the level of system usability. An easy-to-use system will represent that the system has been well developed [52], [53]. In addition, it will be positively affecting user satisfaction. The second indicator is a flexibility that explains a system's ability to accommodate a user's needs [54]. In this case, an e-learning system must accommodate students' needs related to both the learning and administration process. Also, it can respond the user feedback to improve the current system. Next, there is timeliness as an indicator of system quality. This will explain the expected availability time of information that the user needs. A good system quality should provide the required information on time.

In a service quality (X2) variable, there are also three indicators. The first indicator is responsiveness, explaining that the system can quickly and accurately respond to the user's order. Next, there is a functionality as a service system indicator. There are several features of the e-learning system, such as online courses, self-registration, examination, and so on [55]. The functionality indicators ensure that the system features are complete according to student needs, and it works properly. Then, the third indicator is interactivity. The elearning system must be able to provide two-way communication [56]. For examples, student and lecturer both as a user in a learning process or user and administrator for quality improvement purposes.

Afterward, there is user satisfaction (Y1) as a mediating variable. Three indicators can measure this. System satisfaction as a first indicator explains general satisfaction after using the system. The students feel that they are satisfied doing online learning through the system. The expectation fulfillment will then evaluate that the system meets students' needs thoroughly, such as content, features, function, and design. Then the last indicator is the user's interest to continue using system that explains the system sustainability. In general, students feel that the system is suitable for use not only at particular times (this pandemic situation) but can be used continually used in the future as well.

Eventually, a student's individual performance (Y2) is the final outcome measured for the conceptual model. Four indicators represent this variable. The first indicator is a performance improvement related to the learning process. The system must be able to assist and simplify student works such as online classes, learning material availability, tasks collection, and so on [57]. Then, there is an effectiveness improvement. The system is supposed to make learning more effective by providing a service whenever users want and wherever users are. Next, the system also can save time for doing a certain task. The students can save time searching a learning material, looking for new information, collecting an assignment, etc. And the last indicator of the students' individual performance is knowledge improvement. By providing the newest and accurate information and learning material, the system will help the student improve their knowledge.

\section{Conclusion}

This proposed conceptual model can be used as a basic reference to evaluate e-learning system success and its impact on students' individual performance through the e-learning system. DeLone and McLean Information Systems Success Model (DMISSM) was used as the basic model for this conceptual model as this model is considered ideal for evaluating an e-learning IS through user satisfaction and has been widely used in previous related research to measure the success of IS. Each variable of this conceptual model has its own indicators: indicators for System Quality are ease of use, flexibility, and timeliness; indicators for Service Quality are responsiveness, functionality, and interactivity; indicators for User Satisfaction are satisfaction with e-learning, expectation fulfillment, and interest to continue using system; and indicators for Student's Individual Performance are performance improvement, effectiveness improvement, time saving, and knowledge improvement. Conceptual model produced by this study proposes that user satisfaction acts as mediating variable for the relationship between system quality and service quality towards student's individual performance. The result of this study can be used as a basic reference to perform a similar study related to the evaluation of e-learning or distance learning information system.

\section{References}

[1] A. H. Aldholay, A. M. Mutahar, Z. Abdullah, T. Ramayah, and O. Isaac, "Online learning usage and performance among students within public universities in Yemen," in Int. J. Serv. Stand., vol. 12, no. 2, pp. 163-179, 2018.

[2] H. D. Hermawan, N. Deswila, and D. N. Yunita, "Implementation of ICT in Education in Indonesia During 2004-2017," in 2018 International Symposium on Educational Technology (ISET), Jul. 2018, pp. 108-112.

[3] R. C. Clark and R. E. Mayer, e-Learning and the Science of Instruction: Proven Guidelines for Consumers and Designers of Multimedia Learning: Third Edition, 4th ed. London: Wiley, 2012.

[4] K. Schwab, "The Global Competitiveness Report 2019," Geneva, 2019. Accessed: Mar. 29, 2020.

[Online] Available:

http://www3.weforum.org/docs/WEF_TheGlobalCompetitivenessReport 2019.pdf.

[5] Kemendikbud, "SE Mendikbud: Pembelajaran secara Daring dan Bekerja dari Rumah untuk Mencegah Penyebaran Covid-19," Jakarta, Mar. 2020.

[6] C. Dong, S. Cao, and H. Li, "Young children's online learning during COVID-19 pandemic: Chinese parents' beliefs and attitudes," in Child. Youth Serv. Rev., vol. 118, p. 105440, Nov. 2020.

[7] E. Hussein, S. Daoud, H. Alrabaiah, and R. Badawi, "Exploring undergraduate students' attitudes towards emergency online learning during COVID-19: A case from the UAE," in Child. Youth Serv. Rev., vol. 119, p. 105699, Dec. 2020.

[8] R. Rasmitadila et al., "The Perceptions of Primary School Teachers of Online Learning during the COVID-19 Pandemic Period: A Case Study in Indonesia," in J. Ethn. Cult. Stud., vol. 7, no. 2, p. 90, Jul. 2020. 
[9] S. Hidayatullah, U. Khouroh, I. Windhyastiti, R. G. Patalo, and A. Waris, "Implementasi Model Kesuksesan Sistem Informasi DeLone and McLean Terhadap Sistem Pembelajaran Berbasis Aplikasi Zoom Di Saat Pandemi Covid-19," in J. Teknol. dan Manaj. Inform., vol. 6, no. 1, pp. 44-52, 2020.

[10] D. N. Aini, S. Retnantiti, and D. Syafrudin, "E-Learning Media as Learning Resources in State University of Malang," in J. Deutsch als Fremdspr. Indones., vol. 1, no. 1, pp. 8-25, 2017.

[11] D. Nugraheni, "Analisis Penerimaan Dan Kesuksesan Implementasi ELearning Universitas Brawijaya Pada Aspek Intention to Use, Use, User Satisfaction Dan Net Benefits," Brawijaya University, 2017.

[12] S. Aminah, "Pengaruh Pembelajaran Matematika Diskrit dengan Blended Learning terhadap Hasil Belajar," in MUST J. Math. Educ. Sci. Technol., vol. 3, no. 1, pp. 22-32, 2018.

[13] A. H. Almala, "Who Are the Key Stakeholders in a Quality E-Learning Environment?," Distance Learn., vol. 3, no. 4, Jun. 2006.

[14] A. Bhardwaj and S. Goundar, "Student's Perspective of eLearning and the Future of Education with MOOCs," in Int. J. Comput. Sci. Eng., vol. 7, no. 5 , pp. $248-260$, Sep. 2018

[15] W. H. DeLone and E. R. McLean, "Information Systems Success: The Quest for the Dependent Variable," in Inf. Syst. Res., vol. 3, no. 1, Mar. 1992.

[16] W. H. Delone and E. R. McLean, "The Delone and McLean model of information systems success: A Ten-year update," in J. Manag. Inf. Syst., vol. 19, 2003.

[17] E. M. Rogers, Diffusion of Innovations, 4th ed. New York, NY and London: The Free Press, 1995.

[18] M. K. Chang and W. Cheung, "Determinants of the intention to use Internet/WWW at work: a confirmatory study," in Inf. Manag., vol. 39, no. 1 , Nov. 2001

[19] V. Venkatesh, M. G. Morris, G. B. Davis, and F. D. Davis, "User Acceptance of Information Technology: Toward a Unified View," in MIS $Q$., vol. 27, no. 3, pp. 425-478, 2003.

[20] A. K. M. N. Islam, "Investigating e-learning system usage outcomes in the university context," in Comput. Educ., vol. 69, Nov. 2013.

[21] O. Isaac, Z. Abdullah, T. Ramayah, and A. M. Mutahar, "Internet Usage within Government Institutions in Yemen: An Extended Technology Acceptance Model (TAM) with Internet Self-Efficacy and Performance Impact," in Sci. Int., vol. 29, no. 4, pp. 737-747, Jul. 2017.

[22] O. Isaac, Z. Abdullah, T. Ramayah, and A. M. Mutahar, "Internet Usage and Net Benefit among Employees within Government Institutions in Yemen: An Extension of DeLone \& McLean Information Systems Success Model (DMISM) with Task-Technology Fit," in Int. J. Soft Comput., vol. 12, no. 3, pp. 178-198, Jun. 2017.

[23] O. Isaac, Z. Abdullah, T. Ramayah, and A. M. Mutahar, "Examining the Relationship Between Overall Quality, User Satisfaction and Internet Usage: An Integrated Individual, Technological, Organizational and Social Perspective," in Asian J. Inf. Technol., vol. 16, no. 1, pp. 100-124, Jun. 2017.

[24] O. Isaac, Z. Abdullah, T. Ramayah, and A. M. Mutahar, "Towards a better understanding of internet technology usage by Yemeni employees in the public sector: an extension of the task-technology fit (TTF) model," in Res. J. Appl. Sci., vol. 12, no. 2, pp. 205-223, Jul. 2017.

[25] O. Isaac, Z. Abdullah, T. Ramayah, and A. M. Mutahar, "Internet usage, user satisfaction, task-technology fit, and performance impact among public sector employees in Yemen," in Int. J. Inf. Learn. Technol., vol. 34, no. 3, Jun. 2017.

[26] G. P. Z. Montesdioca and A. C. G. Maçada, "Measuring user satisfaction with information security practices," in Comput. Secur., vol. 48, Feb. 2015.

[27] F. Wahyudi, H. Respati, and Y. T. Ardianto, "Study on DAPODIK Information System: User Satisfaction as Mediation of System Quality and Information Quality on Net Benefit," in Inf. Knowl. Manag., vol. 7, no. 7, pp. 53-62, 2017.

[28] M. Althonayan and A. Althonayan, "E-government system evaluation: the case of users performance using ERP systems in higher education," in Transform. Gov. People, Process Policy, vol. 11, no. 3, Aug. 2017.

[29] A. Aldholay, Z. Abdullah, O. Isaac, and A. M. Mutahar, "Perspective of Yemeni students on use of online learning," in Inf. Technol. People, vol. 33, no. 1, Apr. 2019.

[30] G. Chopra, P. Madan, P. Jaisingh, and P. Bhaskar, "Effectiveness of elearning portal from students' perspective," in Interact. Technol. Smart Educ., vol. 16, no. 2, Jun. 2019.

[31] M. Althonayan and A. Althonayan, "E-government system evaluation," in Transform. Gov. People, Process Policy, vol. 11, no. 3, Aug. 2017.
[32] I. Muda, A. Afrina, and E. -, "Influence of human resources to the effect of system quality and information quality on the user satisfaction of accrual-based accounting system," in Contaduría y Adm., vol. 64, no. 2, p. 100 , Oct. 2018.

[33] C. Gürkut and M. Nat, "Important Factors Affecting Student Information System Quality and Satisfaction," in EURASIA J. Math. Sci. Technol. Educ., vol. 14, no. 3, Dec. 2017.

[34] M. A. Hossain, "Assessing m-Health success in Bangladesh," in $J$. Enterp. Inf. Manag., vol. 29, no. 5, Sep. 2016.

[35] P. Ifinedo and N. Nahar, "ERP systems success: an empirical analysis of how two organizational stakeholder groups prioritize and evaluate relevant measures," in Enterp. Inf. Syst., vol. 1, no. 1, Feb. 2007.

[36] Y. Gong and M. Janssen, "Measuring process flexibility and agility," 2010.

[37] M. Stodnick and P. Rogers, "Using SERVQUAL to Measure the Quality of the Classroom Experience," in Decis. Sci. J. Innov. Educ., vol. 6, no. 1, Jan. 2008.

[38] L. Pham, S. Williamson, and R. Berry, "Student Perceptions of ELearning Service Quality, E-Satisfaction, and E-Loyalty," in Int. J. Enterp. Inf. Syst., vol. 14, no. 3, pp. 19-40, Jul. 2018

[39] R. E. Mayer, "Using multimedia for e-learning," in J. Comput. Assist. Learn., vol. 33, no. 5, pp. 403-423, 2017.

[40] D. Abrego-Almazán, Y. Sánchez Tovar, and J. M. Medina Quintero, "Influence of information systems on organizational results," in Contaduría y Adm., vol. 62, no. 2, Apr. 2017.

[41] H. Xinli, "Effectiveness of information technology in reducing corruption in China," in Electron. Libr., vol. 33, no. 1, Feb. 2015.

[42] S. B. Eom, H. J. Wen, and N. Ashill, "The Determinants of Students' Perceived Learning Outcomes and Satisfaction in University Online Education: An Empirical Investigation," in Decis. Sci. J. Innov. Educ., vol. 4, no. 2, pp. 215-235, 2006.

[43] V. Arkorful and N. Abaidoo, "The role of e-learning, advantages and disadvantages of its adoption in higher education," in Int. J. Instr. Technol. Distance Learn., vol. 12, no. 1, pp. 29-42, 2015.

[44] M. J. Kintu, C. Zhu, and E. Kagambe, "Blended learning effectiveness: the relationship between student characteristics, design features and outcomes," in Int. J. Educ. Technol. High. Educ., vol. 14, no. 1, p. 7, 2017.

[45] P. A. Reynolds, "UDENTE (Universal Dental E-Learning) a golden opportunity for dental education," in Bull. du Group. Int. Pour la Rech. Sci. en Stomatol. Odontol., vol. 50, no. 3, pp. 11-19, 2012.

[46] C. M. Chiu, C.-S. Chiu, and H. C. Chang, "Examining the integrated influence of fairness and quality on learners' satisfaction and Web-based learning continuance intention," in Inf. Syst. J., vol. 17, no. 3, Jul. 2007.

[47] D. X. Ding, P. J.-H. Hu, and O. R. L. Sheng, "e-SELFQUAL: A scale for measuring online self-service quality," in J. Bus. Res., vol. 64, no. 5, May 2011.

[48] Y. A. Park and U. Gretzel, "Success Factors for Destination Marketing Web Sites: A Qualitative Meta-Analysis," in J. Travel Res., vol. 46, no. 1, Aug. 2007.

[49] Y. S. Li, W. P. Yu, C. F. Liu, S. H. Shieh, and B. H. Yang, "An exploratory study of the relationship between learning styles and academic performance among students in different nursing programs," in Contemp Nurse, no. October 2014, pp. 4470-4499, 2014.

[50] O. Isaac, Y. Masoud, S. Samad, and Z. Abdullah, "The mediating effect of strategic implementation between strategy formulation and organizational performance within government institutions in Yemen," in Res. J. Appl. Sci., vol. 11, no. 10, 2016.

[51] M. D. Norzaidi, S. C. Chong, R. Murali, and M. I. Salwani, "Intranet usage and managers' performance in the port industry," in Ind. Manag. Data Syst., vol. 107, no. 8, Oct. 2007.

[52] D. Yuniarto, M. Suryadi, E. Firmansyah, D. Herdiana, A. Subiyakto, and A. B. A. Rahman, "Integrating the Readiness and Usability Models for Assessing the Information System Use," in 2018 6th International Conference on Cyber and IT Service Management (CITSM), Aug. 2018, pp. 1-6.

[53] V. N. Helia, V. I. Asri, E. Kusrini, and S. Miranda, "Modified technology acceptance model for hospital information system evaluation - a case study," in MATEC Web Conf., vol. 154, p. 01101, Feb. 2018.

[54] S. Chen, J. Yan, and Q. Ke, "An Investigation to the Impacts of Information Systems Flexibility on Information Systems Strategy Implementation," in HCI in Business, Government and Organizations. Information Systems and Analytics, N. FH. and K. Siau, Eds. 2019, pp. $33-41$. 
[55] T. L. Chou, J. J. Wu, and C. C. Tsai, "Research Trends and Features of Critical Thinking Studies in E-Learning Environments: A Review," in $J$. Educ. Comput. Res., vol. 57, no. 4, pp. 1038-1077, Jul. 2019.
[56] B. Zhang, "A personalised digital classroom with improved interactive responses," in World Trans. Eng. Technol. Educ., vol. 14, no. 1, pp. 95$100,2016$.

[57] H. Kauffman, "A review of predictive factors of student success in and satisfaction with online learning," in Res. Learn. Technol., vol. 23, 2015. 